\title{
Drinking water: a need met for the people of the commune of Bantè, Benin
}

\author{
T. R. Fousseni \\ Master's in socio-anthropology, Manager water supply projet, Zou/Collines programme, \\ NGO RACINES, 273 Savalou, Benin
}

\begin{abstract}
RACINES (Recherches, Actions Communautaires, Initiatives pour un Nouvel ESpoir) is a Beninese non-governmental organization established in 1999 following the initiatives of young Beninese executives. A case study undertaken in 2003 in the villages of Galata and Agbon in the commune of Bantè identified the need for drinking water as the most urgent need. In response to this need, and with the financial support of Oxfam Québec, RACINES initiated a project for the installation of manual water pumps in the two villages. The development of this project involved three major phases: the mobilization of communities around this project, the installation of water pumps and the organization of socio-sanitary educational activities. Twenty months into the execution of the project, a local management committee was established and strengthened, a hand-operated water pump was installed and water-themed public awareness activities, such as water use, water sanitation and the dangers of drinking dirty or contaminated water, were organized every month or so in each of the two communities. Overall, this project has introduced a new type of leadership in the commune of Bantè, involving a high level of participation by young people working alongside the elders in the local management committees and ensuring the perpetuation of the systems installed.
\end{abstract}

\section{Introduction}

Water is a vital resource that constitutes a new strategic issue that mobilizes the entire international community in facilitating its access as well as ensuring its rational management. The attention paid to the water issue, as seen in the successive summits held in Rio de Janeiro and Johannesburg, is an indication of the crucial importance of this precious liquid, which is so great as to be included among the eight Millennium Development Goals (MDGs) established by the United Nations Development Programme. Thus, access to safe drinking water remains a government priority, particularly in Africa, where this resource continues to be in extremely short supply (United Nations System: MDG, target $7 \mathrm{c}$ ).

Aware of the limitations of the efforts of the various SubSaharan African countries, non-governmental organizations (NGOs) are increasingly rallying to contribute to provide drinking water to the working class populations of the cities and the outlying regions.

RACINES, a Beninese non-governmental organization, did not sit on the sidelines of this concern. By taking the position of a community development player, and with the financial support of Oxfam Québec, it initiated a manual water pump installation project in the villages of Galata and Agbon in the commune of Bantè.

The following sections define the context for the implementation of the project, the activities organized and the results obtained from social mobilization and community participation.

\section{Description of the study location}

The Republic of Benin, located in West Africa, covers an area of $114789 \mathrm{~km}^{2}$ and has a total population of 6769914 inhabitants, $51.5 \%$ of whom are women (RGPH3, 2002). The average population density of the country is 59 inhabitants per $\mathrm{km}^{2}$, with a demographic growth rate of $3.2 \%$. The majority of the population (61.1\%) lives in rural areas and has a predominantly polygamist regime, involving $45 \%$ of women aged from 15 to 49 years and $29 \%$ of men from 15 to 64 years (INSAE, 2001-EDSB2).

The administrative organization of the country is divided into 12 départements, 77 communes, 568 districts and 3378 villages and city burroughs. 


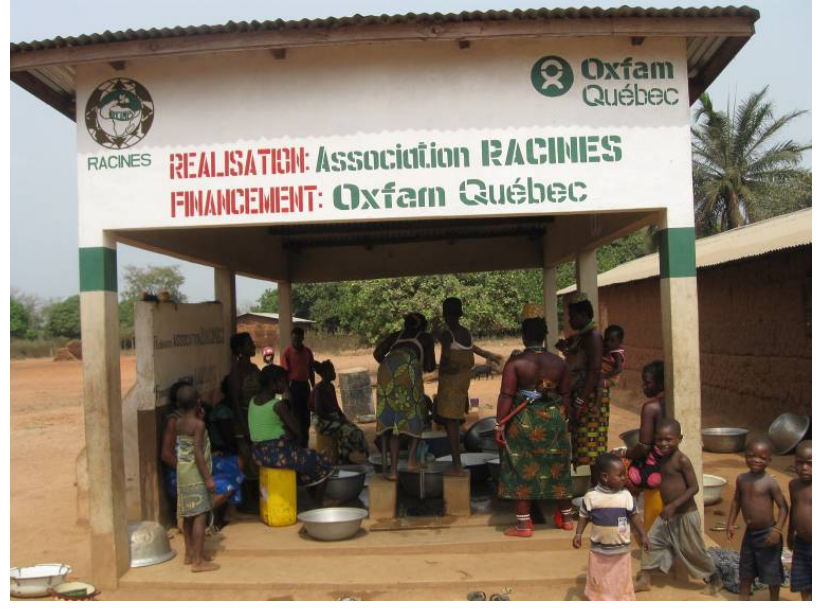

Figure 1. The two hand-operated water pump in the villages of Galata.

Bantè, one of the 77 communes of Benin, is located in the North-West part of the Département des Collines, $292 \mathrm{~km}$ from Cotonou. It covers an area of $2695 \mathrm{~km}^{2}$ and $19.44 \%$ of the Collines territory and includes 9 districts with 34 villages. In 2002, the population of the commune of Bantè was estimated at 82129 inhabitants, $51 \%$ of whom were women (Atlas monographique du Bénin, 2001).

The water system network of the Commune of Bantè is essentially made up of rivers, backwaters and a small number of streams that dry up during the dry season. The populations of this commune, mainly from the villages of Galata and Agbon, get their water supplies from rivers and backwaters. Indeed, Galata, which is one of the 34 villages of the Commune of Bantè and has a population of about 2417 inhabitants, had only two functional water pumps before the implementation of the project, representing a ratio of 1 pump per 1209 inhabitants. The shortage of drinking water in Galata forced the population - in order to avoid long line-ups at existing water pumps - to walk long distances to get water supplies, which they would obtain from backwater and rivers.

The reality faced by the village of Agbon is very similar to that in Galata. Prior to the implementation of the project, Agbon, with a population of about 3515 inhabitants, had only 3 functional water pumps, or a ratio of 1 water pump per 1172 inhabitants. The consequences of such a situation are identical to those observed in Galata. The inability of the two villages to obtain adequate supplies of drinking water accounts for the high prevalence of diseases related to the fecal contamination of water such as cholera, parasitosis and gastroenteritis.

\section{Implementation of project activities}

Faced with the grim circumstances described above, RACINES, with the financial support of Oxfam Québec, con-

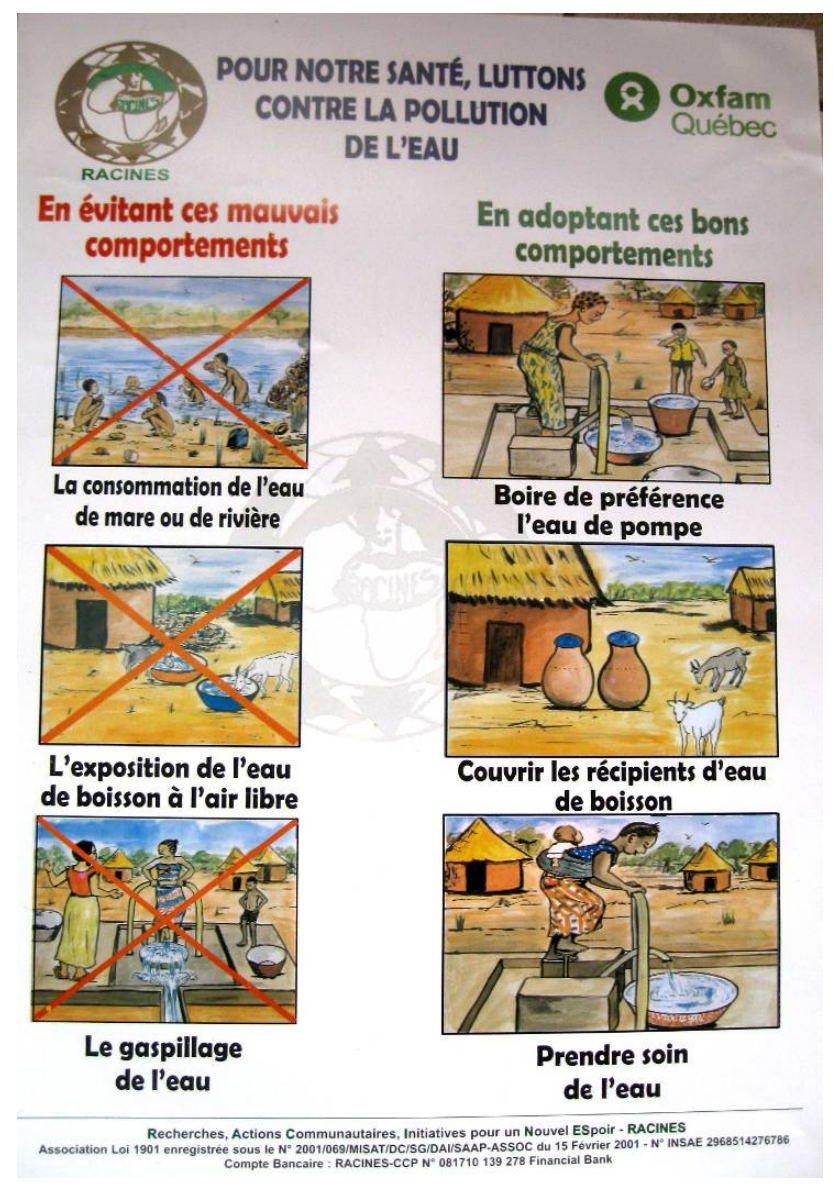

Figure 2. Poster used to raise population awareness for water issue.

tributed to the reduction of various waterborne diseases by implementing a project that involved the installation of two hand-operated water pumps in the villages of Galata and Agbon (Fig. 1).

The overall objective of the project was to contribute to the improvement of the quality of life of the inhabitants of the two villages, mainly of youth and children, by decreasing the occurrence of waterborne diseases through access to a new system of manual water pumps. This overall objective was subdivided into several specific objectives, which involved activities, results and steps to be taken, as summarized in Table 1.

\section{Results}

During the preparatory phase of the project, educational material was developed, consisting in a policy document for the implementation of the project, specification sheets for training, public-awareness posters (Fig. 2) and image boxes (Fig. 3). Through exchange and discussion meetings with the local elected representatives and opinion leaders and the establishment of management committees for the water pumps 
Table 1. Areas of intervention.

\begin{tabular}{|c|c|c|}
\hline Overall Objective & \multicolumn{2}{|c|}{$\begin{array}{l}\text { Contribute to the improvement of the quality of life for inhabitants of the two villages, es } \\
\text { decrease the occurrence of waterborne diseases by giving populations access to new manu }\end{array}$} \\
\hline $\begin{array}{l}\text { Specific } \\
\text { Objectives }\end{array}$ & Activities & Results \\
\hline \multirow[t]{2}{*}{$\begin{array}{l}\text { Prepare operating documents and } \\
\text { public-awareness tools }\end{array}$} & $\begin{array}{l}\text { Develop a policy document for } \\
\text { the implementation of the project }\end{array}$ & $\begin{array}{l}\text { An implementation policy document was devel- } \\
\text { oped, setting out the different stages involved in } \\
\text { carrying out the project and describing the es- } \\
\text { tablishment procedure for and the membership of } \\
\text { the committees that manage the pumps in each of } \\
\text { the beneficiary villages. It also outlined the main } \\
\text { monitoring and project evaluation stages. }\end{array}$ \\
\hline & $\begin{array}{l}\text { Develop training specification } \\
\text { sheets }\end{array}$ & $\begin{array}{l}\text { Specification sheets on key issues concerning wa- } \\
\text { ter management, such as: water use, water sani- } \\
\text { tation, the dangers of drinking dirty and contami- } \\
\text { nated water, group dynamics, water as a finite re- } \\
\text { source and IEC communications techniques have } \\
\text { been developed. Records of meetings and re- } \\
\text { ports have also been developed and prepared for } \\
\text { the management committee's use. The purpose } \\
\text { of these sheets is to provide technical support for } \\
\text { training and for meetings, therefore allowing com- } \\
\text { mittees to be less dependent on the project facili- } \\
\text { tator for the technical management of their various } \\
\text { committees. }\end{array}$ \\
\hline
\end{tabular}

Design public-awareness posters The image boxes and posters are based on the conand image boxes

Enlist the support of local au- Organize information exchange thorities and opinion leaders from both villages for the project. and discussion meetings with local elected representatives and opinion leaders.
District chiefs (DC) of Gouka and Atokokolibé, the village chief and the traditional chief of $\mathrm{Ag}$ bon, the village chief and customary chief of Galata, the youth leaders of Galata and Agbon, women leaders of Galata and Agbon, the people in charge of traditional religion, of the Catholic churches, of the Celestial Church of Christ, of the Methodist Protestant Church of Galata, and the Elders and dignitaries are met separately. In total, twenty-one (21) local elected representatives and opinion leaders - of whom eight (8) are from Galata and thirteen (13) from Agbon - were informed and supported the project. These various meetings allowed every elected member and leader to understand the project objectives and the role entrusted to each of them in as much as they are village entities.

Establish a management commit- Establish management tee for the water pumps in each committees village

Train management committee

members

\begin{tabular}{ll}
\hline $\begin{array}{l}\text { Install and put the water pumps } \\
\text { into operation in the two villages }\end{array}$ & Drilling in Agbon and Galata \\
\hline $\begin{array}{l}\text { Ensure population awareness of } \\
\text { the themes related to water san- }\end{array}$ & $\begin{array}{l}\text { Organize public-awareness- ses- } \\
\text { sions in the communities of the } \\
\text { two villages. }\end{array}$
\end{tabular}

Bi-weekly awareness sessions are organized and led by management committees. A health component was later added to the public-awareness sessions, giving them a more practical rather than theoretical dimension.

A committee of fourteen members (14), preside over by the village chief, was set up in every village. niques.
The image boxes and posters are based on the con-
sumption realities of the two villages. These true organizational communication tools are put at the disposal of every management committee and allow populations who are mostly illiterate to better understand the public-awareness messages. The images from the image boxes represent a summary of the training content, which is based on the public-awareness themes and specification sheets developed.

Approaches

This reference document, developed according to project objectives, serves as a guide for the facilitator as well as the person responsible for the monitoring evaluation.

These sheets were designed taking into account the specificities of each beneficiary village in terms of water use and water management. Once subjected to field tests, the first draft of the said sheets was modified to more accurately reflect the actual needs identified.

First, the facilitator assigned to the project proposed a description of the messages and information to be displayed in the image boxes and posters. An iconographer then produced the drawings before the layouts were taken to the print shop.

Correspondence with an attachment containing the summary of the project was first sent to every leader and local official. Then, exchange and discussion meetings were held with the leaders and officials on an individual basis or in a focus group, which allowed the facilitator a greater opportunity to persuade them of the importance of their full involvement in the project's implementation process.

The members proposed by each organized group from the two villages gathered together to elect the Board.

Each committee was established in its own village. However, a day was devoted to the joint training of the two committees to promote an intermingling and exchange of experiences between the members of committees from the different villages.

The drilling was carried out in three steps: a parcel of land was donated by each village, geotechnical studies were conducted and the drilling itself was then carried out.

The committees define the targets, as well as the themes that will be addressed, depending on the target established, and take note of unsanitary areas that need to be cleaned up. 

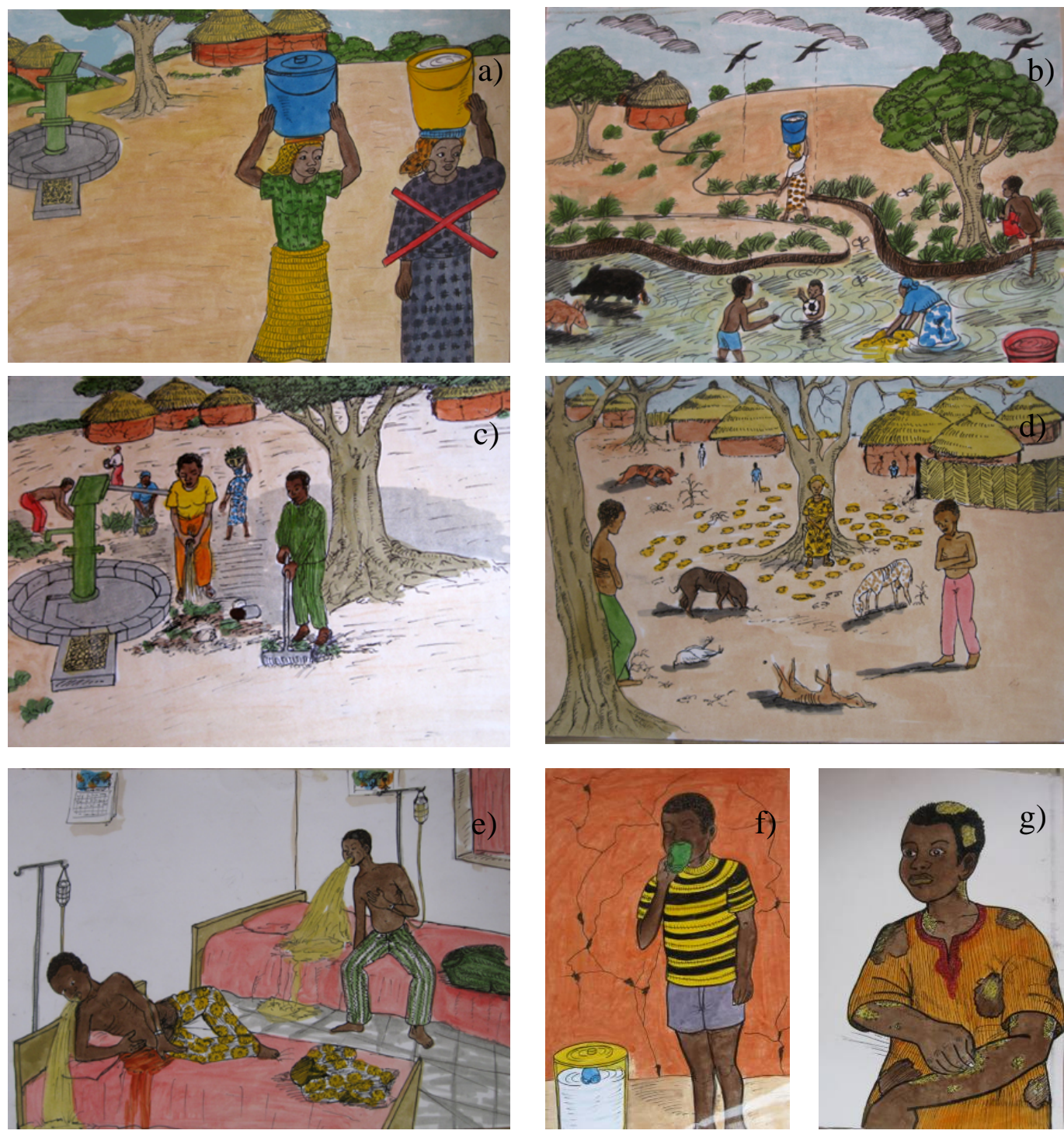

Figure 3. Image boxes used to public education; (a) recommended behavior for water transport, (b) sources for water contamination, (c) public health actions, (d) state of village without water, (e) consequence of contaminated consumption (f) recommended behavior for water consumption, (g) disease related to contaminated water.

in the two villages, an organizational context conducive to the successful implementation of the project was created.

The installation of the pumps took place in three steps: the donation of a parcel of land by each village, the execution of geotechnical studies and the drilling. Since the installation of the pumps, public-awareness sessions on themes related to water sanitation, water use and health have been organized biweekly and are led by management committees.

A first assessment of the project saw an improvement of the initial situation.

As expected, the pumps installed in the two villages considerably lessened the distances covered by most of the members of the villages to obtain a supply of water. The use of the water pumps is an indication that populations are becoming increasingly aware of the dangers involved in drinking dirty or contaminated water; consequently, a decrease can be seen in the number of diseases related to the fecal contamination of water. Tables 2 and 3 shows the changes in the prevalence of these different diseases prior to the implementation of the project, from March 2007 up to October 2008.

Although all cases are not taken into account in the present data, as the rate of visits to health centres establishes itself around $34 \%$ in Benin, and particularly in the two villages, they nevertheless represent the regressive evolution of the diseases identified. 
Table 2. Changes in waterborne disease trends from 2005 to 2008 in the village of Galata.

\begin{tabular}{cccccccc}
\hline & \multicolumn{2}{c}{ Parasitosis } & \multicolumn{2}{c}{ Gastroenteritis } & \multicolumn{2}{c}{ Dysentery } & Total \\
\hline & Men & Women & Men & Women & Men & Women & \\
\hline 2005 & 21 & 19 & 0 & 0 & 0 & 0 & 40 \\
2006 & 21 & 18 & 1 & 0 & 0 & 1 & 40 \\
2007 & 11 & 16 & 1 & 0 & 0 & 0 & 28 \\
2008 & 15 & 9 & 0 & 1 & 0 & 0 & 25 \\
\hline
\end{tabular}

Source: Health care centre records from UVS Galata and from the health centre in the Gouka district.

Table 3. Statistics showing changes in waterborne disease trends from 2005 to 2008 in the village of Atokokolibé.

\begin{tabular}{cccccccc}
\hline & \multicolumn{2}{c}{ Parasitosis } & \multicolumn{2}{c}{ Gastroenteritis } & \multicolumn{2}{c}{ Dysentery } & Total \\
\hline & Men & Women & Men & Women & Men & Women & \\
\hline 2005 & 4 & 5 & 2 & 1 & 2 & 1 & 15 \\
2006 & 5 & 7 & 3 & 0 & 1 & 3 & 19 \\
2007 & 14 & 8 & 2 & 4 & 5 & 4 & 35 \\
2008 & 14 & 8 & 0 & 2 & 1 & 0 & 25 \\
\hline
\end{tabular}

Source: Health care centre records in the Gouka district.

In Galata, the number of waterborne diseases recorded, which was 40 in 2005 and 2006 decreased from 28 to 25 in 2007 and 2008 respectively. In Agbon, a regressive trend is also recorded. According to the available data, the number of sick people decreased from 35 in 2007 to 25 in 2008.

\section{Discussion}

The manual water pump installation project in the villages of Galata and Agbon is a fairly novel approach, both in its conception and in its implementation. In fact, most of the water pumps drilled in Benin are never accompanied by a concerted effort or by socio-sanitary education sessions, which remain one of the factors of its success.

Successful social mobilization around this project is responsible for its durability and its reproducibility. People from every social class in the two villages were affected and their support enlisted. Therefore, the entire population feels that it has a stake in the systems installed.

The decrease in the prevalence rate of waterborne illnesses during the implementation phase of the project is proof of the positive impact it has had on the beneficiary populations. However, the great challenge still posed is to continue organizing health and public-awareness sessions when the project comes to term in March 2009. The management and sanitation committees are sometimes hard pressed to maintain the scheduled activities they themselves have organized, as most of the various members are farmers and therefore tied to their agricultural work. Therefore, the project facilitator must emphasize the operational reinforcement of the committees to ensure that they can manage their time and consequently organize their activities.

However, in the African context, a decrease in waterborne diseases can not only result from the drilling of water pumps. It must be accompanied by public awareness, as populations are still linked to the social constraints that establish and maintain cultural ties with other water sources such as rivers, backwaters and rain.

One of the major accomplishments of this project worth emphasizing is the introduction of a new type of leadership in the governance of beneficiary populations. Young and old must now work together to manage a community project, a responsibility that was once the exclusive domain of the Elders, as determined by a social hierarchy based on age.

The results obtained from this project confirm the importance of having it duplicated in other villages of the commune of Bantè, where the need for safe drinking water is still deeply felt.

The implementation methodology of this project, initiated by the financial partner, could be reproduced for future similar projects and yield the same results, in Benin as well as in other African countries. As a corollary, exchanges between the Jeunes acteurs du changement (JAC) partners, financed by Oxfam Québec, allow for the exchange of valuable experience within the context of the development of such an initiative. The common goal shared by all these partners remains the mobilization of local populations in support of environmental issues, as it is in Benin, with the association RACINES and other organizations and in Togo with ADETOP. 


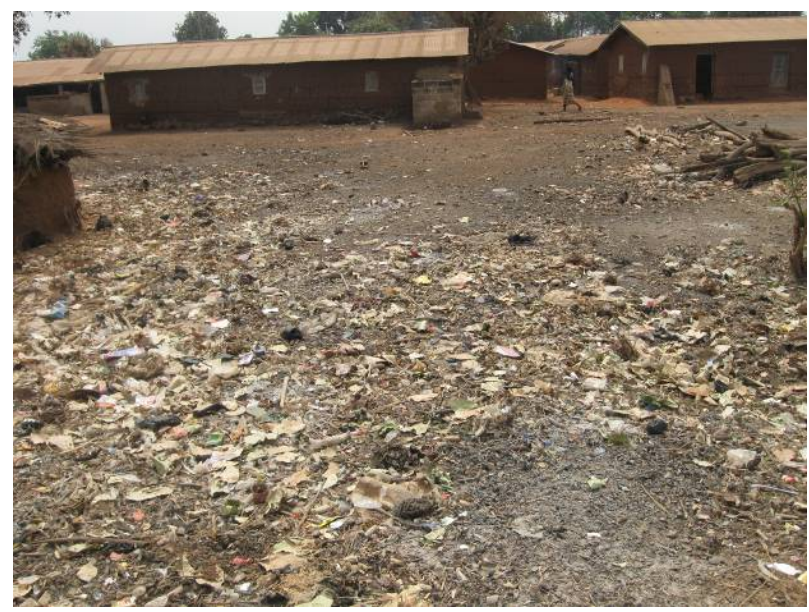

Figure 4. Wild dumps close to homes in Galata.

\subsection{Difficulties encountered}

During the first year of the project's implementation, no major challenges were encountered. Rather, a keen interest was shown by populations rallying in great numbers to attend sessions. It is important to note, however, that because of the field work that must be done, large gatherings can only take place on Sundays, a schedule to which the facilitator must adapt.

Also of note is that the people of Galata - one of the two villages where the intervention took place - are living in an extremely unhealthy environment. A study showed that thirty eight (38) wild dumps are scattered throughout the village and close to homes in Galata (Fig. 4). To make matters worse, more than 1000 pigs run free in the village, leaving fecal matter behind wherever they go (Fig. 4). A prospective analysis of the situation in Galata makes it possible to foresee any risk of compromise of project objectives presently being carried out because of the unhealthy village environment. We therefore had to promote a more extensive sanitation process by strengthening committees previously established and by having them take on greater responsibility towards issues such as health, garbage collection, domestic animal control and the construction of enclosures for animals. Moreover, in accordance with the project's funding partner, funds were allocated to ensure that committees were equipped with the proper tools needed to build a healthy environment, such as hoes, coupe-coupes, brooms, rakes, shovels, gangs, mufflers and trash cans. Consequently, the initial public-awareness activities on water-related themes are now paired with environmental education sessions.

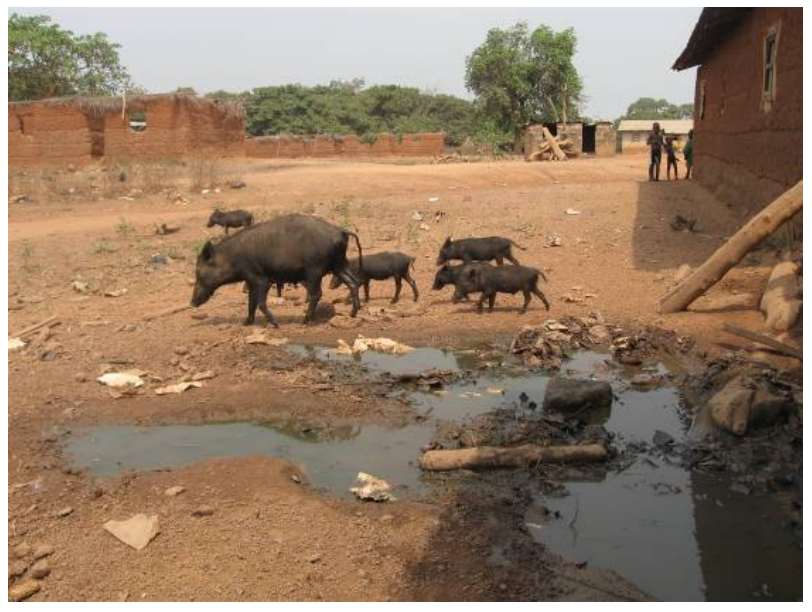

Figure 5. Pigs in Galata.

\section{Conclusions}

One can conclude from the aforementioned that the project for the installation of manual water pumps in the villages of Galata and Agbon responds to an identified need in these populations in terms of its establishment. Many other villages in the commune of Bantè are experiencing the same extreme water shortages faced by Galata and Agbon. The need these communities have for this equipment is so great that they are willing to make many sacrifices to benefit from the same type of project. The approach taken in this project, which promotes the empowerment of populations through comprehensive education about issues concerning water-management, the populations themselves and the establishment of a new type of leadership, will allow the next project of this type in this area to be based on expertise and acquired tools.

\section{References}

Principaux Indicateurs socio-démographiques, Institut National de Statistique et d'Analyses Economiques (INSAE), Direction des Etudes Démographiques, Cotonou, 19 pp., 2003.

Synthèse des Résultats, INSAE, Direction des Etudes Démographiques, Cotonou, 34 pp., 2003.

Premier rapport sur les Objectifs du Millénaire pour le Développement, Conseil National de la Statistique, Cotonou, 28 pp., 2003.

Atlas Monographique des communes du Bénin, Institut Géographique National, Cotonou, 2001. 